\title{
Bilateral isolated cut of sensory branch of radial nerve
}

\author{
Radial sinir duyusal dalının iki taraflı izole kesisi
}

\author{
Nuray AKKAYA, ${ }^{1}$ Hakan Ramazan ÖZCAN, ${ }^{2}$ İnci GÖKALAN KARA, ${ }^{2}$ Füsun ŞAHİN ${ }^{1}$
}

Bilateral injuries of the sensory branch of the radial nerve (SBRN) usually occur as a result of tight-handcuff neuropathy. In this case we aimed to present bilateral isolated cut of SBRN resulting an injury mechanism that has not been reported in the literature previously. A male twentyfour years old, a worker in a glass factory, presented to our clinic. The dorsolateral skin of his wrists were cut by breaking of the glass as a result of occupational accident and was primarily sutured in a healthcare center. The patient sought additional care after a month because of lingering numbness and pain, and surgery was planned. During surgery, scar tissue and neuroma at the cut ends of SBRN were excised, and bilateral SBRN cuts were repaired. Four weeks after operation, mild sensory deficit on the dorsal side of bilateral thumbs, and left first web space and flexion limitation on the right wrist were detected. At the 3rd month postoperative, right wrist joint range of motion was full, and sensory deficits, and hyperesthesia were decreased. The SBRN elicits the sensory innervation of the thumb dorsum and its injury does not cause important functional deficit. However because of susceptibility of SBRN to develop painful neuroma, diagnosis, treatment and follow up of isolated SBRN injury would be worthwhile for prevention of possible painful neuropathy disturbing quality of life.

Key Words: Nerve injury of forearm; neuroma; sensory branch of radial nerve.
Radial sinir duyusal dalının (RSDD) iki taraflı yaralanmaları genellikle sıkı takılmış kelepçe nöropatisi sonucunda oluşur. Bu yazıda daha önce literatürde bildirilmemiş yaralanma mekanizması ile oluşan iki taraflı izole RSDD kesisinin sunulması amaçlandı. Yirmi dört yaşında cam fabrikasında işçi erkek hasta sunuldu. İş kazası sonucu cam kırılması ile el bilekleri dorsolateralinde oluşan cilt kesisi, başvurduğu sağlık merkezinde primer dikilmiş. Hasta 1 ay sonra geçmeyen hissizlik ve ağrı nedeniyle plastik ve rekonstrüktif cerrahi bölümüne başvurdu ve cerrahi planland1. Cerrahi sırasında gözlenen skar doku ve RSDD kesik uçlarında oluşan nöroma temizlendi ve iki taraflı RSDD kesisi tamir edildi. Hastanın fizik tedavi ve rehabilitasyon bölümündeki fiziksel incelemesinde, iki taraflı başparmak dorsal yüzünde ve sol 1. web aralığında hafif duyusal kayıp ve sağ el bileği fleksiyonunda kısıtlılık olduğu saptandı. Ameliyat sonrası 3. ay incelemede sağ el bileği eklem hareket açıklığı tam, duyusal defisitler ve hiperestezi azalmıştı. RSDD başparmak dorsalinin duyusunu sağlar, o nedenle yaralanması önemli fonksiyonel kayıba neden olmaz. Ancak, RSDD’nin ağrılı nöroma gelişimine yatkınlığı nedeniyle, izole RSDD yaralanmasının tanı, tedavi ve takibinin yapılması yaşam kalitesini bozan olası ağrılı nöropatinin önlemesi için faydalı olacaktır.

Anahtar Sözcükler: Önkol sinir yaralanması; nöroma; radial sinir duyusal dalı.
The superficial branch of the radial nerve (SBRN) is a peripheral nerve which is commonly injured along with the common peroneal and spinal accessory nerves, and can be easily repaired. ${ }^{[1]}$ SBRN injury may be caused by fractures, lacerations or iatrogenic mechanisms. ${ }^{[2-4]}$ It was reported that SBRN divides into 3 branches on the dorsolateral aspect of the wrist in $90 \%$ of explored cadavers. SBNR1 extends over the dor- sal side of the index finger, SBNR2 extends over the dorsal side of the first web space and SBRN3 extends over the dorsolateral side of the thumb. ${ }^{[5]}$ SBRN injury typically results in numbness, paresthesia on the dorsal side of first web space and thumb, and the formation of painful neuroma. ${ }^{[1]}$ In the literature, unilateral SBRN injuries were reported due to fractures, compression of mass or iatrogenic causes ${ }^{[2-4]}$ bilateral SBRN injuries
Departments of ${ }^{1}$ Physical Medicine and Rehabilitation, ${ }^{2}$ Plastic and Reconstructive Surgery, Pamukkale University Faculty of Medicine, Denizli, Turkey.
Pamukkale Üniversitesi Tıp Fakültesi, ${ }^{1}$ Fizik Tedavi ve Rehabilitasyon

Anabilim Dalı, ${ }^{2}$ Plastik ve Rekonstrüktif Cerrahi Anabilim Dalı, Denizli.

Correspondence (Illetişim): Nuray Akkaya, M.D. Pamukkale Üniv. Tıp Fakültesi, Fizik Tedavi ve Rehabilitasyon Anabilim Dalı, Kınıklı, 20070 Denizli, Turkey. Tel: +90 - 258 - 4440728 e-mail (e-posta): nrakkaya@gmail.com 


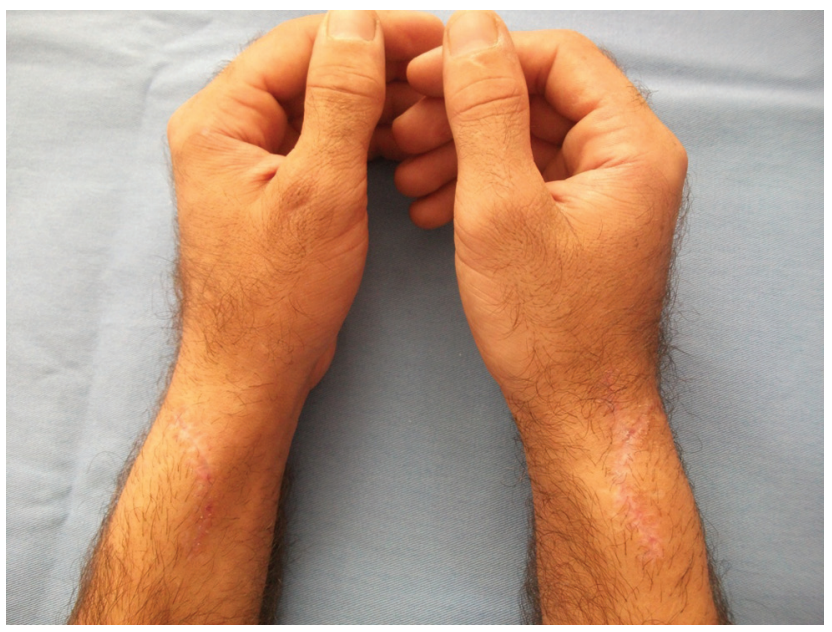

Fig. 1. Scars on wrist anterolateral.

(Color figures can be viewed in the online issue, which is available at www.tjtes.org).

were reported due to application of tight handcuffs. ${ }^{[6,7]}$ In this case we aimed to present bilateral isolated cut of the SBRN by an injury mechanism that has not been reported in the literature previously. The patient has signed an informed consent form.

\section{CASE REPORT}

A 24-year-old, male patient who was a worker in a glass factory for 10 years presented to our clinic. Skin cuts on the dorsolateral side of bilateral forearms occurred due to breaking of glass while he was carrying a large glass block. Primary suture was completed for his skin cut at a healthcare center. Patient was not wearing gloves or any other protective materials at the time of injury. The patient did not report alcohol or narcotic substances usage. The patient consulted to the Department of Plastic and Reconstructive Surgery after a month due to lingering numbness and pain on the dorsal side of bilateral thumbs and left first web space, and surgery was planned. At the time of surgery it was observed that the ends of bilateral SBRNs had been healed with scar tissue and had formed neuroma. Following excision of scar tissue and neuroma, bilateral SBRN cuts were repaired by the end-to-end epineural repair technique during surgery. After bilateral forearms were encased in a plastersplint, the patient was referred to our Department of Physical Therapy and Rehabilitation for follow up examinations and rehabilitation.

At his physical examination, $5 \mathrm{~cm}$ of injury and surgery scars were seen on both the distal one third of forearms on the dorsolateral as- pect (Fig. 1). His bilateral wrist extension was $55^{\circ}$, right wrist flexion was $40^{\circ}$, left wrist flexion was $70^{\circ}$. The reason behind the limitation of right wrist flexion range of motion may be an immobilization process. For this limitation, the patient was given a physical therapy program including infrarogue, therapeutic ultrasound and exercises postoperatively. Mild sensory deficits were detected on the dorsal side of bilateral thumbs and the left first web space. Motor or sensory deficits in other nerves or in other fingers were not determined. When sensory deficits were evaluated with Semmes-Weinstein Monofilament test, and the dorsal side of bilateral thumbs prior to rehabilitation varied between 3.61-4.31, and the left hand first web space prior to rehabilitation varied between 4.56-6.65 (Fig. 2a). He was also taken into a desensitization program. According to the preoperative evaluation of nerve and sensory tests, it was thought that the SBRN3 was injured on the right side, and SBRN2, and SBRN3 were injured in the left side of the patient.

On his postoperative follow up at 3rd month, wrist range of motion was full and when sensory deficits were evaluated with Semmes-Weinstein Monofilament test, bilateral thumb dorsal sensory again varied between 3.61-4.31, and left first web space varied between 4.31-4.56 (Fig. 2b). Hyperesthesia was decreased but still continued.

\section{DISCUSSION}

The radial nerve divides into deep and superficial branches after reaching the forearm. The sensory branch of radial nerve superficially lies on the radial side of the forearm. This superficial course of the nerve makes the SBRN a frequently injured nerve. Patients who are not treated may experience lifetime sensory problems depending on the degree of injury. ${ }^{[8]}$

The reported reasons for unilateral injury of SBRN are: trauma, lipoma or compression of ganglion cyst, radius fracture, damage due to Kirschner wiring of radial fracture, injury by the cannulation of peripheral vein prior to anesthesia, arthroscopy of wrist or due to De Quervain's disease..$^{[2,4,8-10]}$

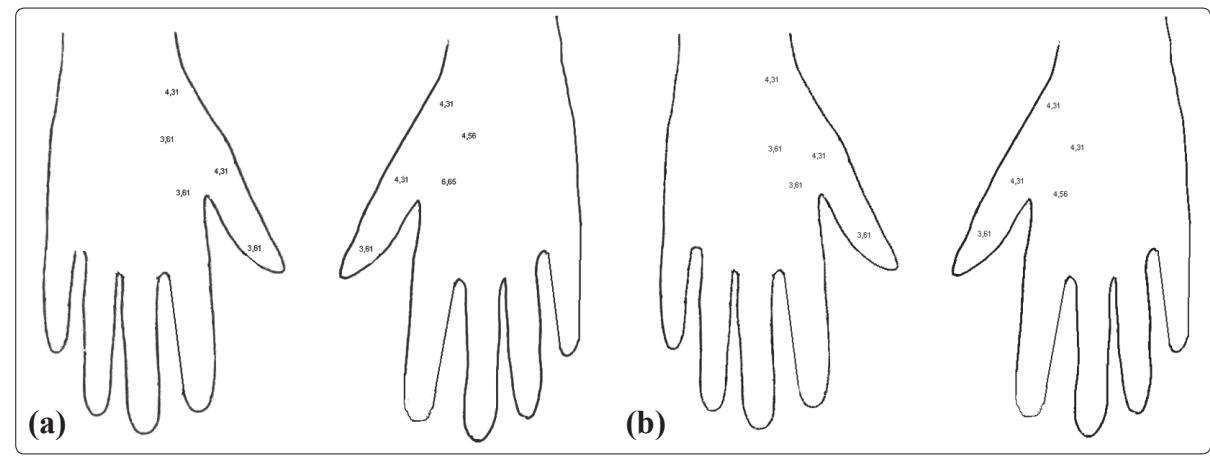

Fig. 2. (a) Semmes-Weinstein monofilament test before treatment. (b) Semmes-Weinstein monofilament test after treatment. 
Bilateral radial nerve paralysis is a rare incident. ${ }^{[11]}$ It has been reported that median, ulnar or multiple nerves could be damaged by tight handcuffs, however the SBRN is the most commonly injured nerve following application of tight handcuffs. ${ }^{[12]}$ These SBNR injury cases often occur under the influence of alcohol or narcotic substances. ${ }^{[7]} \mathrm{SBRN}$ becomes prone to injury by compression of tight handcuffs at the distal lateral radius. ${ }^{[3]}$ In this case, however, the patient had an occupational injury independent of the effects of alcohol or narcotic substances.

Nerve injuries in the upper limb are usually combined injuries with arterial or tendon damage and occur mostly at distal forearm or wrist. ${ }^{[13]}$ In our patient, the injury was dorsolateral of the wrists. However in this case the injury resulted in isolated SBRN cut because of the anatomic features of the SBRN and the injury mechanism. While the SBRN lies laterally to the radial artery in the middle third of the forearm at the radial side, it is distanced from the radial artery in the lower third of forearm. ${ }^{[5]}$ Although the SBRN is adjacent to the radial artery in the middle part of the forearm, in this case the injury was on the lower part of forearm, which led to isolated SBRN cut. Thus the patient may have been saved from the probable concomitant radial artery injury. Moreover, the presence of only SBRN3 cut on the right wrist, and only SBRN2 and SBRN3 cut on the left wrist were interesting, with the SBRN1 intact bilaterally. In this case, injuries occurred at approximately below the distribution of the SBRN, resulting in this type of cut in the SBRN branches.

Dellon et al. ${ }^{[14]}$ reported that because of an anatomic mechanism, SBRN is more prone to develop neuroma than the palmar cutaneous branch of the median nerve and dorsal cutaneous branch of ulnar nerve. Ciaramitaro et al. ${ }^{[15]}$ determined that traumatic neuropathies are usually seen in males and on upper limbs, and $72 \%$ of traumatic neuropathies were painful. In addition, a strong correlation was found between the severity of neuropathic pain and quality of life. ${ }^{[15]}$ In our case, the skin cut was primarily sutured following the injury. Because of the continuation of pain and paresthesia, the patient consulted again. When the patient had the surgery for SBRN injury diagnosis, the presence of neuroma between cut ends of SBRN was observed. His pain passed and paresthesia decreased after surgery. On his postoperative follow up, it was determined that his left first web space sensory also improved.

Injury of SBRN does not cause direct negative effects to hand function because it is purely a sensory branch. However sensory deficits because of inadequate healing of the nerve following laceration of SBRN may have negative effects on hand functions, making the hand more prone to injury. Furthermore, probable development of painful neuroma decreases the quality of life. Early diagnosis, treatment and good follow up may be effective for prevention of these complications. It should be emphasized that persons handling incisory-poignant, searing subjects, as seen in our case, must take precautions to reduce hand injuries.

In conclusion, even though peripheral sensory nerve injury does not cause motor deficits, diagnosis of SBRN cut is important because of the probable development of painful neuroma. Therefore injuries of SBRN should be diagnosed early, and properly treated to avoid negative effects of injury on quality of life.

Conflict-of-interest issues regarding the authorship or article: None declared.

\section{REFERENCES}

1. Robson AJ, See MS, Ellis H. Applied anatomy of the superficial branch of the radial nerve. Clin Anat 2008;21:38-45.

2. Tosun N, Tuncay I, Akpinar F. Entrapment of the sensory branch of the radial nerve (Wartenberg's syndrome): an unusual cause. Tohoku J Exp Med 2001;193:251-4.

3. Grant AC, Cook AA. A prospective study of handcuff neuropathies. Muscle Nerve 2000;23:933-8.

4. Singh S, Trikha P, Twyman R. Superficial radial nerve damage due to Kirschner wiring of the radius. Injury 2005;36:330-2.

5. Ikiz ZA, Uçerler H. Anatomic characteristics and clinical importance of the superficial branch of the radial nerve. Surg Radiol Anat 2004;26:453-8.

6. Dellon AL, Mackinnon SE. Radial sensory nerve entrapment in the forearm. J Hand Surg Am 1986;11:199-205.

7. Haddad FS, Goddard NJ, Kanvinde RN, Burke F. Complaints of pain after use of handcuffs should not be dismissed. BMJ 1999;318:55.

8. Boeson MB, Hranchook A, Stoller J. Peripheral nerve injury from intravenous cannulation: a case report. AANA J 2000;68:53-7.

9. Jou IM, Wang HN, Wang PH, Yong IS, Su WR. Compression of the radial nerve at the elbow by a ganglion: two case reports. J Med Case Rep 2009;3:7258.

10. Amar MF, Benjelloun H, Ammoumri O, Marzouki A, Mernissi FZ, Boutayeb F. Anatomical snuffbox lipoma causing nervous compression. A case report. [Article in French] Ann Chir Plast Esthet 2012;57:409-11. [Abstract]

11. Sturzenegger M, Rutz M. Bilateral radial nerve paralysis. Diagnostic and differential diagnostic aspects. Schweiz Med Wochenschr 1990;120:1325-34. [Abstract]

12. Levin RA, Felsenthal G. Handcuff neuropathy: two unusual cases. Arch Phys Med Rehabil 1984;65:41-3.

13. Ozdemir HM, Biber E, Oğün T. The results of nerve repair in combined nerve-tendon injuries of the forearm. Ulus Travma Acil Cerrahi Derg 2004;10:51-6.

14. Dellon AL, Mackinnon SE. Susceptibility of the superficial sensory branch of the radial nerve to form painful neuromas. J Hand Surg Br 1984;9:42-5.

15. Ciaramitaro P, Mondelli M, Logullo F, Grimaldi S, Battiston B, Sard A, et al. Traumatic peripheral nerve injuries: epidemiological findings, neuropathic pain and quality of life in 158 patients. J Peripher Nerv Syst 2010;15:120-7. 